\title{
Effectiveness of Good Governance in Government Management of Fixed Assets (Case Study on Goods and Asset Management Bureau Secretariat Province of South Sulawesi)
}

\author{
Mediaty $^{1}$, Kastumuni Harto ${ }^{2}$, Dinah Diyanah Burhan ${ }^{3}$ \\ \{unhasmediaty@gmail.com ${ }^{1}$, kastumuniharto@yahoo.co.id ${ }^{2}$, diiinadb@gmail.com ${ }^{3}$ \} \\ Faculty of Economic and Business, Universitas Hasanuddin ${ }^{1,2,3}$
}

\begin{abstract}
This study aimed to analyze the application of the principles of good governance: accountability and transparency in the management of fixed assets of the local government. This type of research is descriptive quantitative research. Respondents in this study of 40 people who are employees of the Asset Management Bureau Goods and South Sulawesi Provincial Secretariat. This study uses a questionnaire (primary data), and the results were analyzed using multiple linear regression analysis. The results showed that the accountability and transparency of a positive influence on the management of fixed assets of the local government.
\end{abstract}

Keywords: Accountability, good governance, management of fixed assets, transparency.

\section{Introduction}

Good governance is recognized by the world with good governance. Good governance is becoming known in Indonesia in 1998 on good governance, but the concept itself is already there in the 20th century in the western world. Good governance is governance that is considered most effective in applying in a government. A concept that is considered the world can improve governance is not running properly.

Assets in local government are usually called the property area. Understanding local property according to Permendagri 17 of 2007 are all goods purchased/obtained at the expense of the Regional Budget or other legitimate acquisition so it can be concluded that the property of blood is something that is owned and controlled by local, regional understanding of property is in line with the notion of assets. Local government assets sometimes become problems encountered when an audit for local governments.

Mulalinda and Steven J. (2014) found the process of implementation of systems and procedures for asset/property area has not been effective in several subsystems [1]. Ovine Triski Piri (2016) in his research mentioned asset management in the area of the Integrated Licensing Services Office has not been effective because it does not apply to the whole system and procedure contained in Regulation 17 of 2007. Based on these studies contained in asset management subsystems are prone to run with no maximum as in the process of receiving, storing, distributing assets, inventory, security, and claim for compensation [2]. 
Implementation of good governance in local governments should be able to be one of the solutions to reduce the risks in asset management. Therefore, the authors are interested in doing a study entitled "Effectiveness of Good Governance in Local Government Fixed Assets Management (Case Study Bureau of Property Manager and Asset South Sulawesi Provincial Secretariat)".

Accountability is an obligation for government officials to act as responsible and personnel accountable for their actions and policies set [3]. Stewardship theory in Jefri (2018:19) is defined as an attitude and behavior that puts the long-term interests of the group above personal goals that serve one's own interests. Accountability for individual activities carried on his work influence the long-term interests of the group. This theory can support the employee/government personnel in carrying out asset management activities to remain accountable for the continuation of the relevant agencies [4]. Based on the theory that has been put forward, the hypothesis in this study summed up as:

H1: Implementation of accountability have a significant influence on the management of fixed assets of local government

Transparency in the process of public policy formulation and implementation is the nature of good governance. Pristiani and Amir (2016: 2) [5], stewardship theory describes a situation where the management is not motivated by the goals of individuals but rather aimed at their main objectives for the benefit of the organization. If placed on the public sector as the management of the head, SKPD has contributed to the organizational goals that can only be achieved if the information is true, transparent, and well-directed to any staff/employee there [5]. Locke in Sari (2016: 120) argues that good goal setting is an appropriate goal setting and consistent from top to bottom level. Determination of such objectives can be achieved if information about the spread of overall organizational goals and understandable to employees at the top level to the bottom level of the organization. Transparency is very important in setting the organization's objectives [6]. Based on the theory that has been described previously, then the hypothesis in this study summed up as:

H2: The application of transparency has a significant influence on the management of fixed assets of local government

\section{Research Methodology}

\subsection{Research design}

This research is a quantitative descriptive method. This research method is used to show how much the relationship of good governance in the management of fixed assets and also find out the extent to which good governance has been established in local government by using the data that will be collected and processed by the existing theory. The independent variable in this study is good governance, the rule of law, accountability, transparency, effectiveness, and efficiency as the indicator. The dependent variable in this study is the management of fixed assets. 


\subsection{Population and Sample}

The population in this study is all of the units within the scope of the regional work units (SKPD) that are within the scope of the Bureau of Assets Management and Asset Secretariat of South Sulawesi which includes three sub-parts: 1) part of the administration, use, utilization and removal, 2) the administration business, planning and standardization, and 3) part of the security, maintenance, and supplies. The total population is 60 people. Based on the total population, the sample size was calculated based on the formula below. Once calculated into the formula, then obtained a total of 37.5 which is then rounded up to 40 , and thus the total sample in this study was 40 .

\subsection{Data Analysis}

The method for data analysis used in this study is the method of statistical analysis using SPSS. Statistical analysis will be used as a statistical analysis by multiple linear regression method. Data quality testing using test reliability and validity test. Testing the hypothesis in this study was conducted with a simultaneous test ( $\mathrm{F}$ test), partial test (t-test), and the coefficient of determination (R2).

\section{Result and Discussion}

Multiple linear regression equation in this study were obtained as follows:

$$
\mathrm{Y}=\mathrm{a}+\mathrm{b} 1+\mathrm{b} 2 \mathrm{X} 1 \mathrm{X} 2+\mathrm{e}
$$

$$
\text { Fixed asset management }=12.157+(0.297) \mathrm{X} 1+(0.342) \mathrm{X} 2+\text { is }
$$

Based on the above equation it can be seen a positive constant value amounted to 12.157 show the positive influence of independent variables (accountability and transparency), this means that each increment of the independent variable or influence in one unit then the variable management of fixed assets will rise. Regression coefficient value of variable accountability (X1) for the management of fixed assets (Y) positive worth of 0.297 , which means the relationship of accountability variables and variable, fixed asset management is positive. Each increase of one unit of a variable asset management accountability, the variable will be increased by 0.297 or $29.7 \%$. The regression coefficient on the variable transparency (X2) on fixed asset management variable (Y) is positive 0.342 , which means that the variable transparency and fixed asset management variables are positively related. The increase of one unit in the variable transparency will increase fixed asset management amounted to 0.342 or $34.2 \%$.

\subsection{Effect of Fixed Assets Management Accountability Against}

Statistical test the hypothesis testing on accountability variable (X2) found that the value of the regression coefficient of 0.006 and $2.941 t_{\text {count }}$ with positive values. This shows that there is a significant relationship between the variables of accountability for the management of fixed assets that are positive. The first hypothesis is acceptable because the regression 
coefficient of accountability $<0.05$ and $t_{\text {count }}$ greater value $t_{\text {table }}$ is 0.2030 . Based on these results, we conclude that the partial accountability effect on the management of fixed assets.

In the public sector, there is a liability in each period in order to determine the work carried out has reached the target or not. Human nature is responsible mentioned in stewardship theory, which supports the implementation of accountability in the management of fixed assets. Accountability for individual activities carried on his work influence the longterm interests of the group. This theory can support the employee/government personnel in carrying out asset management activities to remain accountable for the continuation of the relevant agencies.

Implementation of accountability that supports the theory of stewardship in the management of fixed assets can improve the performance of the management of fixed assets. The application can also avoid the accountability of collusion, corruption, and nepotism in the asset management area that is a harmful region. Effect of accountability in the management of fixed assets contained in the first hypothesis, which states that accountability significantly positive effect on the management of fixed assets of the local government.

\subsection{Effect of Transparency Against Fixed Asset Management}

Variable regression coefficient value of 0.02 and positive transparency is $t_{\text {count }} 3.264$ on statistical test in hypothesis testing. Sig. Less than 0.05 and greater $t_{\text {count }}$ than $t_{\text {tabel }} 0.2030$ proves that there is a positive effect on the variable transparency of the management of fixed assets, the second hypothesis is accepted. Based on these results, we conclude that transparency significantly positively related partially to the management of fixed assets.

Stewardship theory according to Pristiani and Amir (2016: 2), describes a situation where the management is not motivated by the goals of individuals but rather aimed at their main objectives for the benefit of the organization. If placed on the public sector as the management of the head, SKPD has contributed to the organizational goals that can only be achieved if the information is true, transparent, and well-directed to any staff/employee there. An understanding of the organization's objectives in this regard the management of fixed assets will have a positive effect and avoid the occurrence of errors in decision making [5].

Application of stewardship theory and the theory of goal setting on transparency can be very supportive in improving the performance of the asset management area. Transparency of information can help local governments to repair bad assumptions in the community about the government that is not released from collusion, corruption, and nepotism in it. With transparency, the public can know the things that have been done by the government and also monitor and provide input to the government in order to improve things that are not running properly.

The relationship of transparency in asset management has a very close relationship. This is consistent with the results described in the second hypothesis. The statement in the second hypothesis is transparency significantly positively related to the management of fixed assets of local government.

\section{Conclusion}

Accountability and transparency of significant positive effect on the management of fixed assets of the local government. This is evident from every improvement that occurred in these 
variables to make improvements to the management of fixed assets. Likewise, if there is a decrease in these variables will lead to a decrease in fixed asset management.

\section{Research suggestions}

Subsequent research in order to put on another method by adding some populations and the object of research to get a diverse and accurate data and add another variable to measure the factors that affect the management of fixed assets.

\section{References}

[1] Mulalinda, V., and Tangkuman, S. J.: "Efektivitas penerapan sistem dan prosedur akuntansi aset tetap pada dinas pendapatan, pengelolaan keuangan dan aset daerah kabupaten sitaro," Jurnal EMBA: Jurnal Riset Ekonomi, Manajemen, Bisnis dan Akuntansi, vol. 2, no. 1, pp. 521$531,2014$.

[2] Ovine, Riski Piri.: Analisis Efektivitas Pengelolaan Barang Milik Daerah di Kantor Pelayanan Perizinan Terpadu Provinsi Sulawesi Utara. Jurnal EMBA: Jurnal Riset Ekonomi, Manajemen, Bisnis dan Akuntansi. vol. 4, no. 1 (2016).

[3] Mardiasmo.: Akuntansi Sektor Publik. Andi: Yogyakarta (2002).

[4] Jefri. R.: Teori Stewardship Dan Good Governance. Economics Bosowa. vol. 4, no. 3, pp. 14 28 (2018).

[5] Pristiani, P and Mahmud, A.: Perbedaan Pemahaman Standar Akuntansi Pemerintahan (SAP) Berbasis Akrual Berdasarkan Demografi Pegawai. Accounting Analysis Journal. vol. 5, no. 1 (2016).

[6] Locke. E. A, Shaw. K. N, Saari. L. M, and Latham. G. P.: Goal setting and task performance: 1969-1980. Psychological bulletin. vol. 90, no. 1, pp. 125 (1981). 